\title{
PERFORMANCE PERSISTENCE AND GAMMA CONVERGENCE IN ABSOLUTE RETURN FUNDS IN POLAND OVER THE PERIOD 2011-2018
}

\author{
Jadwiga Machnik \\ Wroclaw University of Economics and Business, Wroclaw, Poland \\ e-mail: jadwiga.machnik@ue.wroc.pl \\ ORCID: 0000-0002-6189-1797 \\ (C) 2020 Jadwiga Machnik \\ This work is licensed under the Creative Commons Attribution-ShareAlike 4.0 International License. \\ To view a copy of this license, visit http://creativecommons.org/licenses/by-sa/4.0/
}

Quote as: Machnik, J. (2020). Performance persistence and gamma convergence in absolute return funds in Poland over the period 2011-2018. Financial Sciences, 25(2-3).

DOI: $10.15611 /$ fins.2020.2.03

JEL Classification: G11, G23

\begin{abstract}
This article attempts to analyse the investment performance of absolute return funds in 2011-2018 in Poland from the point of view of their performance persistence and the occurrence of gamma convergence. Two research hypotheses were verified. The first one is that absolute return funds do not maintain their investment results, while the second deals with the occurrence of the gamma convergence phenomenon on the absolute return funds market. The research methods adopted, i.e. the contingency tables as a non-parametric method of measuring the maintenance of investment results, and gamma convergence as one of the convergence measures, allowed to reach appropriate conclusions. Performance persistence does not occur in most of the analysed cases. In the case of gamma convergence the obtained resultse indicated the occurrence of this phenomenon on the absolute return funds market.
\end{abstract}

Keywords: performance persistence, absolute return funds, gamma convergence.

\section{Introduction}

The financial market of absolute return funds is relatively young and still developing in Poland, although it has existed for several years. The small quantity of funds which function continuously makes it hard to estimate current trends; estimation is essential for different time frames. The literature review showed that few analyses have concentrated on absolute return funds so far, therefore there are new perspectives for an empirical investigation with regard to the analysis of the repeatability of the performance of the absolute return funds. 
Past rates of return provide scientists and investors with significant information concerning these funds, and also take into account previous financial decisions of fund managers. It is very difficult to determine the future rates of return of investment funds based on historical rates of return. However, one can indicate whether and for how long fund managers can maintain their investment performance over a certain period of time, called performance persistence in the literature. Therefore this is the point of verifying the repeatability of investment fund performance. One can indicate whether the funds are consistently achieving good or bad results in subsequent periods (Perez, 2012, p. 245).

Convergence, on the other hand, discusses the subject of reducing the diversity of entities included in a given sample in terms of the variable characterizing the examined phenomenon which occurs in the mentioned entities. The gamma convergence factor determines the change of position of the examined objects in the ranking (Dittmann, 2014, p. 199).

In fact, there are only few research focusing on investment results' repeatability in Central and Eastern European countries. Therefore, it seems interesting to analyse this phenomenon in the case of absolute return funds, which are an alternative to traditional portfolio investments in this region. One can observe the development of these funds, which began with the financial crisis in 2007. Moreover, gamma convergence has not yet been used to analyse the investment fund market.

Studies on the repeatability of absolute return funds are important for investors and managers of collective investment entities. For investors, the results of such research can be crucial information in making investment decisions. Analysis of the performance of absolute return funds can help in the evaluation of investment policy and organisational solutions by the analysed funds.

Thus the aim of this paper is to analyse the repeatability of investment results of absolute return funds operating on the Polish market in the period 2011-2018. This will be achieved by studying two phenomena: performance persistence and gamma convergence.

The phenomena mentioned above can be described as complementary. The use of performance persistence made it possible to identify funds for which there was a recurrence of good or bad results in subsequent periods and those funds that achieved the opposite: once good and once bad in consecutive periods. The study also drew attention to gamma convergence, suspecting its existence in the absolute return funds market, with regard to the repeatability of investment performance. In the case of this phenomenon, the analysed funds were also sorted in terms of the rates of return achieved in particular periods, but from the highest rate of return to the lowest. In this way, it was possible to find out whether a specific fund that achieved the best result in the first period also maintained this trend in subsequent years. Hence it was possible to answer the question of the repeatability of good and bad results.

The author verified two hypotheses: 
1. Performance persistence of absolute return funds did not exist on the Polish domestic market over the period 2011-2018.

2 . The phenomenon of gamma convergence could be observed on the market of Polish absolute return funds in 2011-2018.

\section{Literature review}

\section{Performance persistence}

The first studies on performance persistence in investment funds date back to the 1960s and concern mainly the US market. Sharpe (1966, pp. 119-138) and McDonald (1974, p. 325) compared the value of the reward-to-variability ratio's fund with those calculated for analogous funds a decade earlier. The results of the research indicated that it is possible to predict differences in the results achieved by the first or last ranked funds, however in an imperfect way. Rates of return of the funds in the tested samples were measured by the Sharpe index. McDonald and Sharpe conducted a series of other studies that indicated that historical rates of return did not play a significant role in predicting future investment performance for a particular period. Ippolito (1993, pp. 42-50), and Grinblatt and Titman (1989, pp. 393-416) came to similar conclusions as Sharpe and McDonald. They chose Jensen's alpha factor as a measure of return rates.

Hendricks, Patel and Zeckhauser (1993, pp. 93-130) carried out research on a sample of 165 share growth funds between 1974 and 1988 and for the following time horizons: $3,6,12$ and 24 months. The results of the research confirmed the occurrence of persistence in the case of the weakest funds. However it is difficult to confirm the persistence, referring to the funds occupying the highest positions in the rankings, in the long term.

Brown and Goetzmann (1995, pp. 679-698) as well as Elton, Blake and Gruber (1996, pp. 133-157) chose, among others, the one and three-factor Jensen alpha, which allowed them to find the relationship between the time horizon and the maintenance of investment funds on certain positions in the rankings. According to these researchers, high ranking positions are viable to achieve in the long (5 or 10-year) and medium (2 or 3-year) periods.

Philpot, Hearth, Rimbey and Schulman (1998, pp. 115-125), as well as Polwitoon and Tawatnuntachai (2006, pp. 2767-2786), focused their attention on the American bond market. They proved that there can be no question of the occurrence of the persistence phenomenon in the long run. They analysed the accepted research samples and chose common rates of return, as well as Sharpe's coefficient. On the other hand, the short-term results indicate weak performance by certain funds.

The research in the early 2000s extended the field of research into the performance persistence of investment funds. Ferruz, Vicente and Andreu (2007, pp. 583-594) analysed the Spanish equity pension funds' market over the period 1999-2006. They 
provided proof for performance persistence in short-term (yearly analysed periods), using the method of contingency tables.

In 2011, Huang and Mahieu (2011, pp. 17-34) decided to examine the Dutch industry-wide pension funds. They claimed that the analysed sample did not obtain their benchmarks coherently from 1998 to 2006, and noted the lack of performance persistence for the test sample.

One can observe different findings by analysing research conducted in Central and Eastern Asia. The first concerned China's equity funds' market over the period January 2004-December 2014. Rao, Iqbal and Tauni (2016, pp. 146-156) stated that their research did not confirm the occurrence performance persistence for the analysed sample, unlike the results for the United States. These findings are different from those provided by Chowdhury, Ali, Usman and Ullah (2020, pp. 1728-1748), who observed performance persistence in the short-run for Bangladesh's equity mutual funds between 2010 and 2015.

Regarding the performance persistence research in Central and Eastern Europe, one can point to, among others, D. Filip (2011, pp. 18-34), who focused on equity funds in Hungary, taking into account two time horizons: 1-year and 6-month. The empirical results showed that there is dependence in subsequent periods; short-term performance persistence was found for the studied horizon: from 2000 to 2009.

Filip in cooperation with Jackowicz (2009, pp. 8-52) also analysed a sample consisting of share and hybrid Polish funds operating in 2000-2007. They proved performance persistence in the short term, especially in the case of the analysed share funds. However, in their opinion the results achieved did not stem from the skill of the fund managers. According to the researchers, the mentioned phenomenon is a result of market factors.

One can also point to the research conducted by Perez (2012, pp. 265-274). Among others, she analysed a sample consisting in share funds as well as hybrid funds operating in Poland from 1999 to 2004, using the Sharpe, Treynor and Jensen indicators. The research showed that it is impossible to confirm the occurrence of the persistence for the analysed funds for two and three-year time intervals.

Filip (2013, pp. 324-342) also verified the performance persistence phenomenon for equity funds in the Czech market. The result of his research confirmed the occurrence of weak performance persistence from 2000 to 2010. The contingency tables and stochastic kernel estimation were tapped.

\section{Gamma convergence}

Convergence discusses the subject of reducing the diversity of entities included in a given sample in terms of the variable characterizing the examined phenomenon which occurs in the mentioned entities.

Convergence has been studied, among other things, in the context of income equalisation between countries so far. Today, the world is characterized by a strong 
stratification of income which leads to an increase in the disparities between countries and significant disproportions in living standards. Since the 1980s and 1990 s, international researchers have been using convergence to find answers to the question about the causes of this income stratification. They use measures of economic activity such as GDP per capita. Barro and Sala-i-Martin (1992, pp. 223-251) indicated that $\beta$-convergence is most commonly applied in inter-regional studies. They asked whether regions with lower incipient GDP tend to grow considerably faster than regions with higher incipient GDP.

The theme of real convergence was also taken up by Boyle and McCarthy (1999, pp. 343-347). They used the GDP per capita measure to determine the occurrence of $\sigma$-convergence and $\gamma$-convergence for the four-country block defined by World Bank typology during the period 1960-1992.

Gripaios, Bishop and Keast (2000, pp. 1161-1167) wanted to prove the existence of the convergence of gross domestic product per capita in the counties of UK over the period 1977-1995, and the overall results led to the rejection of the hypothesis of convergence. However, some evidence pointed to the existence of gamma convergence in Northern Britain in the 1990s.

Research on economic convergence has become popular in Poland since 2004. In that time Poland has become a part of the regional policy of the European Union. The real convergence of the CEE countries was dealt with by, among others, Matkowski, Próchniak and Rapacki (2013, pp. 63-98). They presented forecasts for reducing the income gap between Poland and other CEE countries and Western Europe. The relevant data were taken from the period 1994-2010. Próchniak (2019, pp. 217-243) conducted further studies to check the convergence of 28 European Union (EU) member states and 16 non-EU post-socialist countries in 2019. The results of his research confirmed the occurrence of convergence of $\beta-, \sigma$ - and $\gamma$ for the analysed sample in the period 1995-2018.

The studies from the beginning of the first decade of this century showed that convergence (and its different types) can be used not only in the context of income equalisation between countries. Convergence was also examined in terms of prices. Dittmann (2014, pp. 195-207) used gamma convergence to analyse changes in the average offer and transaction prices of $1 \mathrm{~m} 2$ on the primary and secondary housing markets in Poland. The study, which covered, among others, 16 voivodeship cities, did not show the occurrence of gamma convergence. On the other hand, Wyrzykowski (2015, pp. 356-361), analysed the process of the convergence of food prices in the European Union in 1999-2014. The results of the research confirmed the convergence of beta and sigma for general food prices.

Twardowska (2019, pp. 133-143) asked her article if it is possible to indicate a decrease in the price differential of agricultural land in the European Union countries by using the convergence. The conducted research confirmed the occurrence of the sigma-convergence of agricultural land prices in the whole EU over the period 2006-2016 . 
Convergence has also been used to analyse the housing market. In this area, the research mainly concerned the empirical verification of price convergence in local and regional housing markets. Initially, US and UK market researchers sought to establish whether housing prices tend to develop stable balances at regional or international level (Kim and Rous, 2012; MacDonald and Taylor, 1993). In addition to price convergence, real convergence studies were carried out in the literature on the functioning of housing markets, which determines the similarity of the structures of the respondents' economies, including ownership structure, and the evolution of their institutional environment (Chiu, 2008; Governa and Saccomani 2010; Kusideł, Kucharska-Stasiak, Załęczna, and Żelazowski, 2020; Żelazowski, 2018).

The convergence of beta, sigma and gamma was also used to examine the dynamics of financing newly established companies. The authors of the study focused on the initial financing decisions and their significance for future financing decisions. Data from French manufacturing companies established between 2004-2006 were used (Hirsch and Walz, 2017, pp. 261-272).

Convergence was also applied to the issue of the tax burden in the European Union in terms of increasing economic integration and tax harmonisation policies. The convergence of beta, sigma and gamma was analysed by Delgado (2009, pp. 141-166).

\section{Data and methodology}

The data contained on the website Analizy Online, indicated the existence of 44 funds with the absolute rate of return as of 13.12.2018 (analiz.pl). However, only 12 funds on the Polish market were classified in the sample operating continuously from 2011 to 2018 (Table 1).

Table 1. Division of absolute return funds on the Polish market operating continuously in 2011-2018

\begin{tabular}{|l|l|}
\hline \multirow{4}{*}{$\begin{array}{l}\text { UNIVERSAL ABSOLUTE RETURN } \\
\text { FUNDS }\end{array}$} & Investor FIZ \\
\cline { 2 - 2 } & Millennium Absolute Return (Millennium SFIO) \\
\cline { 2 - 2 } & Noble Fund Global Return (Noble Funds FIO) \\
\cline { 2 - 2 } & Opera Alfa-plus.pl (Opera SFIO) \\
\cline { 2 - 2 } & Opera Za 3 Grosze FIZ \\
\cline { 2 - 2 } & PZU Aktywny Akcji Globalnych (PZU FIO Parasolowy) \\
\cline { 2 - 2 } & Rockbridge FIO Strategii Akcyjnej \\
\cline { 2 - 2 } $\begin{array}{l}\text { ALTERNATIVE ABSOLUTE RATE } \\
\text { OF RETURN FUNDS }\end{array}$ & Rockbridge Selektywny (Rockbridge FIO Parasolowy) \\
\cline { 2 - 2 } & Skarbiec Market Opportunities (Skarbiec FIO) \\
\cline { 2 - 3 } & Superfund GREEN (Superfund SFIO) \\
\cline { 2 - 3 } & Superfund Trend Plus Powiązany SFIO kat. Standardowa \\
\hline
\end{tabular}

Source: own compilation based on data published at (Analizy, 2018). 
The study was conducted in three different periods, taking into account the one, two and four-year consistency (Table 2).

Table 2. Ranking periods $(t)$ and persistence periods $(t+1)$ in the study of the performance persistence of Polish absolute return funds in 2011-2018

\begin{tabular}{|c|c|c|c|}
\hline & Ranking period $(t)$ & Persistence period $(t+1)$ & Observations \\
\hline \multirow[t]{4}{*}{1} & \multirow[t]{4}{*}{1 year } & \multirow[t]{4}{*}{1 year } & 2011-2012 \\
\hline & & & 2012-2013 \\
\hline & & & $\ldots$ \\
\hline & & & 2017-2018 \\
\hline \multirow[t]{3}{*}{2} & \multirow{3}{*}{2 years } & \multirow[t]{3}{*}{2 years } & 2011-2012 and 2013-2014 \\
\hline & & & 2013-2014 and 2015-2016 \\
\hline & & & 2015-2016 and 2017-2018 \\
\hline 3 & 4 years & 4 years & 2011-2014 and 2015-2018 \\
\hline
\end{tabular}

Source: own compilation.

Statistical and economic inferences concerning the performance persistence of investment funds can be conducted by using the parametric method, which is a linear regression, as well as non-parametric methods which may include Spearman's rank correlation, contingency table and other non-parametric tests, including bootstrapping methods. Currently the most common method is the contingency table.

In order to analyse the performance persistence of absolute return funds, the study used the method of the contingency table. The persistence test was performed for one type of measure (logarithmic rate of return), three different periods, and one type of funds. This table was created on the basis of a list of the best and the worst funds, valuing the funds by taking into account the investment results achieved by these funds in period $t-1$. In the next step it was checked whether the funds in the examined sample again obtained the highest or the lowest investment results in period $t$. Next the examined funds were assigned to the group of winners (WW, winners-winners) or losers (LL, losers-losers). In a situation where certain funds in periods $t-1$ and $t$ were in opposite groups, i.e. in period $t-1$ they were classified to the group of winners (losers), but in period $t$ they achieved results assigning them to the group of losers (winners), they were defined as WL (winners-losers) or LW (losers-winners).

Once the funds were arranged into four groups, the next step was to calculate the CPR (cross-product ratio). Comparing the number of funds in group of WW or LL to the number of funds which were characterized by variable levels of investment performance, one can provide an accurate ratio (Arouri, Boubaker, and Nguyen, 2014, p. 317): 


$$
C P R=\frac{W W \times L L}{W L \times L W},
$$

where $W W, L L, W L$ and $L W$ are the number of funds that are in a specific group.

The value of CPR $=1$ indicates that there are no reasons for rejecting the $H_{0}$ hypothesis which states lack of performance persistence. However, $C P R>1$ is an indication for rejecting the $H_{0}$ hypothesis on account of the $H_{1}$ hypothesis: the occurrence of performance persistence.

Statistics $Z$ or $\chi^{2}$ allow researchers to verify the statistical significance of the CPR. Referring to the $\mathrm{Z}$ statistics with asymptotically normal distribution, the following relation is mentioned (Casarin, Lazzarin, Pelizzon, and Sartore, 2003, p. 16):

$$
Z=\frac{\ln C P R}{\sigma_{\ln \mathrm{CPR}}}
$$

for which the standard deviation of the natural logarithm is represented by the following formula:

$$
\sigma_{l n \mathrm{CPR}}=\sqrt{\frac{1}{W W}+\frac{1}{W L}+\frac{1}{L W}+\frac{1}{L L}} .
$$

If the results indicate an inequality $|Z| \geq Z_{\alpha}$, where $Z_{\alpha}$, is the critical value $Z$, reaching $2.58,1.96$ or 1.65 , respectively, to a confidence interval $1 \%, 5 \%$ or $10 \%$, the $H_{0}$ hypothesis of lack of performance persistence should be rejected in favour of the $H_{1}$ hypothesis of the occurrence performance persistence.

Besides the $\mathrm{Z}$ statistics, one can distinguish the independence test $\chi^{2}$. This allows to verify the statistical significance of the $C P R$. In a situation in which there is no correlation between the investment results of absolute return funds, the study analysed both the observed and expected distribution. The value $\chi^{2}$ was calculated according to the following formula (Perez, 2012, pp. 253-254):

$$
\chi^{2}=\frac{(W W-D 1)^{2}}{D 1}+\frac{(W L-D 2)^{2}}{D 2}+\frac{(L W-D 3)^{3}}{D 3}+\frac{(L L-D 4)^{2}}{D 4},
$$

where:

$$
\begin{aligned}
& D 1=(W W+W L)(W W+L W) / N, \\
& D 2=(W W+W L)(W L+L L) / N, \\
& D 3=(L W+L L)(W W+L W) / N, \\
& D 4=(L W+L L)(W L+L L) / N,
\end{aligned}
$$

and

$$
N=W W+W L+L W+L L
$$


The variable $\chi^{2}$ as an asymptotic distribution with one degree of freedom. Assuming positive values which are greater than the critical value (for the $1 \%, 5 \%$ or $10 \%$ confidence interval the critical value is $6.635,3.841$ and 2.706 , respectively), it indicates the need to reject the $H_{0}$ hypothesis in favour of the $H_{1}$ hypothesis of a statistically significant occurrence of the performance persistence (Perez, 2012, pp. 253-254).

Two studies were conducted in the article. The second methodology refers to the gamma convergence phenomenon. Rankings of funds were constructed on the basis of previously calculated logarithmic rates of return in order to examine the occurrence of the gamma convergence phenomenon.

To determine whether the analysed phenomenon occurred in the sample, the following formula for the gamma convergence coefficient was applied in period $t$ in relation to the period considered as the basis (0) (Dittmann, 2014, p. 200):

$$
\gamma_{t}=\frac{\operatorname{var}\left(r_{i t}+r_{i 0}\right)}{\operatorname{var}\left(2 \times r_{i 0}\right)}
$$

where: $\gamma_{t}$ - convergence coefficient for period $t$, var - variance, $r_{i t}$ - position of the $i$-th object in period $t, r i_{0}$ - position of the $i$-th object in period $0, i=1, \ldots, n$, $n$ - number of objects tested.

The gamma convergence coefficient takes the values in the closed interval from 0 to 1 . The higher the value of this coefficient, the weaker the gamma convergence. One of the tools to verify this phenomenon is Kendall's coefficient of concordance, which takes different forms depending on the number of examined objects. For the purpose of this study (which includes the analysis of the twelve absolute return funds) the following formula was used:

$$
\chi_{t}^{2}=k \times(n-1) \times \gamma_{t} .
$$

The equation above is applicable to the number of objects tested above 7 for period $t$. The author concluded the value of theoretical statistics from the distribution table $\chi_{t}^{2}$ for $n-1$ degrees of freedom and the assumed level of significance $\alpha$. It can be stated that the gamma convergence phenomenon occurs when the value of theoretical statistics is higher than the value of empirical statistics $\chi_{t}^{2}$ (Dittmann, 2014, p. 200).

\section{Results of the tests}

\subsection{Performance persistence in absolute return funds}

The results of the research are presented in Table 3. Analysing the periods 2011-2012, 2013-2014 and 2015-2016, the author concluded that the managers of the funds included in the sample, maintained their investment results. As far as the periods 
2012-2013 and 2014-2015 are concerned, the analysed funds achieved inverse rates of return (evidenced by the negative value of $Z$ statistics). However, in the case of the periods 2016-2017 and 2017-2018, one can observe the non-occurrence of performance persistence as is indicated by the CPR value equal to 1 . Unfortunately, the analysis also showed that the results above were not statistically significant for the assumed levels of materiality $0.01,0.05$ and 0.1 .

For two-year periods, the results clearly indicate a lack of persistence in absolute return funds, also confirmed by the CPR value equal to 1 , whereas tendencies shaped for the four-year data show that the managers were able to maintain their investment results of the analysed absolute return funds. However, in the case of four-year persistence the obtained results are not statistically significant for levels of materiality $0.01,0.05$ and 0.1 , as well as for one-year persistence.

Table 3. Performance persistence tables for Polish absolute return funds 2011-2018

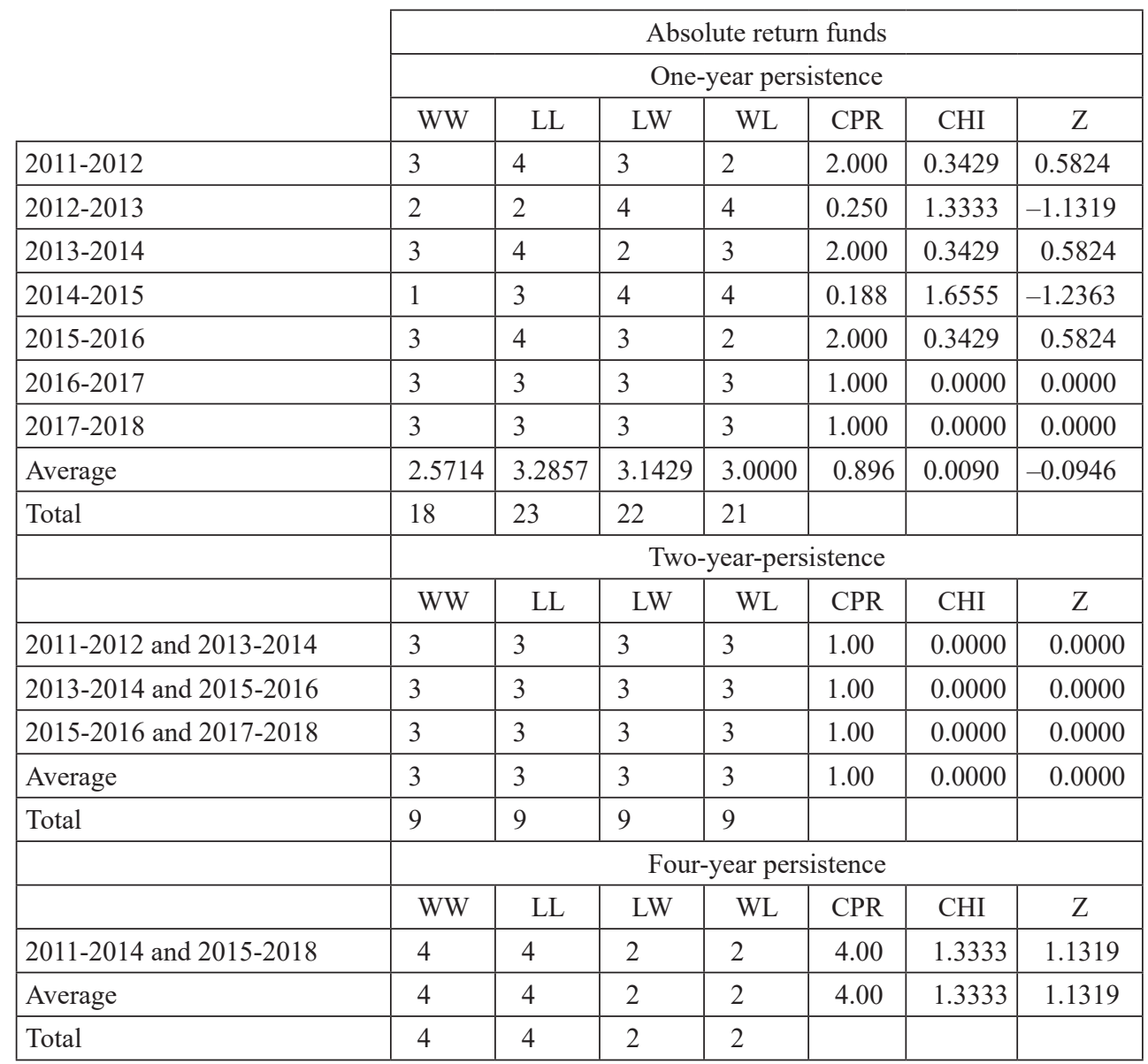

Source: own calculations. 


\subsection{Gamma convergence phenomenon}

The verification of the second research hypothesis required organizing the investment results of these funds from the best to the worst, indicating the occurrence of the gamma convergence among Polish absolute return funds in the period 2011-2018. Hence in the next step, specific gamma convergence coefficients were calculated for the returns of the funds included in the sample. Table 4 contains the results for the conducted survey. For the assumed level of materiality $\alpha=0.05$, the occurrence of gamma convergence of the rate of returns of the analysed funds was found for the period 2012-2018 (the theoretical value of chi square statistics is 19.6751). This is evidenced by the appropriate values of empirical statistics marked in grey in the table below.

In analysing the results above, it should be remembered that the higher the gamma convergence values, the weaker the phenomenon.

Table 4. Values of gamma convergence coefficients $\left(\gamma_{t}\right)$ and empirical statistics $\chi^{2}$

\begin{tabular}{|l|l|l|}
\cline { 2 - 3 } \multicolumn{1}{c|}{} & \multicolumn{2}{c|}{ Absolute return funds } \\
\cline { 2 - 3 } \multicolumn{1}{c|}{} & $\gamma_{t}$ & $\chi^{2}$ \\
\hline 2011 & 1 & 22 \\
\hline 2012 & 0.79 & 17.38 \\
\hline 2013 & 0.437 & 9.615 \\
\hline 2014 & 0.531 & 11.69 \\
\hline 2015 & 0.692 & 15.23 \\
\hline 2016 & 0.801 & 17.62 \\
\hline 2017 & 0.476 & 10.46 \\
\hline 2018 & 0.598 & 13.15 \\
\hline
\end{tabular}

Source: own calculations. Therefore it can be seen that the gamma convergence was weakest in 2016 and strongest in 2013. It is worth noting that the gamma convergence was relatively strong also in the case of the remaining years (except for 2012 for which the gamma convergence coefficient was one of the weakest). As a consequence, there are no grounds for rejecting the $H_{0}$ hypothesis of the volatility of the positions of the analysed absolute return funds in the ranking in favour of the $H_{1}$ hypothesis. As a result, it can be concluded that the managers of the funds that were in the analysed sample did not manage to keep the effectiveness of these funds at a stable level, in almost the whole period (with a few exceptions). This is indicated by the significant volatility of the positions of the observed funds resulting from the relatively strong gamma convergence in the periods 2013-2015 and 2017-2018.

\section{Summary and conclusions}

The main purpose of this article was to assess the occurrence of performance persistence. Moreover, the study analysed the variability of the absolute return funds' position in the ranking created on the basis of the investment results of these funds. Having selected the appropriate methods, the author conducted research to verify the hypotheses set out at the beginning of this study.

The results of the research verifying the performance persistence were statistically insignificant for Polish absolute return funds over 2011-2018 in each of the analysed periods. 
However, the results of research concerning the occurrence of the gamma convergence phenomenon allowed to distinguish the periods for which the diversity of the analysed funds was the most significant. Therefore the managers of the analysed funds were not able to maintain the effectiveness of the funds concerned at a stable level almost over almost the entirely period under analysis (with a few exceptions).

The phenomenon of performance persistence has been rarely studied in Central and Eastern European countries. This study is an attempt to fill this research gap. The gamma convergence phenomenon, on the other hand, has not yet been used to analyse the repeatability of absolute return funds' performance. The increase in the number of absolute return funds is the premise for continuing research into performance persistence and gamma convergence. The research presented in this article can also be used to analyse the results achieved by other collective investment entities in Poland.

\section{References}

Agudo, L. F., Vicente, L., and Andreu, L. (2007). Performance persistence of Spanish pension funds: The best winners and losers usually repeat. Geneva Papers on Risk and Insurance - Issues and Practice, 32(4), 583-594.

Analizy. (2018). Retrieved December, 13, 2018 from https://www.analizy.pl/porownywarka-fundusze-inwestycyjne

Arouri, M., Boubaker, S., and Nguyen, D. C. (2014). Emerging markets and the global economy. A handbook. Oxford: Academic Press, 861-875.

Barro, R. J., and Sala-i-Martin, X. (1992). Convergence. Journal of Political Economy, 100(2), 223$-251$.

Boyle, G. E., and McCarthy, T. G. (1999). Simple measures of convergence in per capita GDP: A note on some further international evidence. Applied Economics Letters, 6(6), 343-347.

Brown, S. J., and Goetzmann, W. N. (1995). Performance persistence. The Journal of Finance, 50(2), 679-698.

Budiono, D. P., and Martens, M. (2010). Mutual funds selection based on funds characteristic. The Journal of Financial Research, 33(3), 249-265.

Casarin, R., Lazzarin, M., Pelizzon, L., and Sartore, D. (2005). Relative benchmark rating and persistence analysis: Evidence from Italian equity funds. The European Journal of Finance, 11(4), 297-308.

Chiu, R. (2008). Government intervention in housing: Convergence and divergence of the Asian Dragons. Urban Policy and Research, 26(3), 249-269.

Chowdhury, M. A., Ali, Z., Usman, M., and Ullah, A. (2020). Performance persistence of mutual funds: Evidence from Bangladesh. Independent Journal of Management \& Production, 11(6), 1739-1759.

Delgado, F. J. (2009). Tax burden in the European Union: An analysis of beta, sigma and gamma convergence. Revista de Economia Mundial, (22), 141-166.

Dittmann, I. (2014). Gamma konwergencja cen na lokalnych rynkach mieszkaniowych w Polsce. Katowice: Wydawnictwo Uniwersytetu Ekonomicznego w Katowicach.

Elton, E. J., Gruber, M. J., and Blake, Ch. R. (1996). The persistence of risk-adjust mutual fund performance. The Journal of Business, 69(2), 133-157. 
Ferruz, L., Vicente, L., and Andreu, L. (2007). Performance persistence of Spanish Pension Funds: The best winners and losers usually repeat. The Geneva Papers on Risk and Insurance - Issues and Practice, 32(4), 583-594.

Jackowicz, K., and Filip, D. (2009). Powtarzalność wyników funduszy inwestycyjnych w Polsce. Materiaty $i$ Studia, (236), 8-52.

Filip, D. (2011). Performance persistence of equity funds in Hungary. Contemporary Economics, 5(1), 18-34.

Filip, D. (2013). Returns and persistence of investment fund performance in the Czech Republic. Prague Economic Papers, 3, 324-342.

Governa, F., and Saccomani, S. (2010). A neo-liberal housing policy? Convergence and divergence between Italian local housing policy and European trends. 24th AESOP Annual Conference, Finland, 7-10 July.

Grinblatt, M., and Titman, S. (1989). Portfolio performance evaluation: Old issues and new insights. The Review of Financial Studies, 2(3), 393-416.

Grinblatt, M., and Sheridan, T. (1989). Mutual fund performance: An analysis of quarterly portfolio holdings. The Journal of Business, 62(3), 393-416.

Gripaios, P., Bishop, P., and Keast, S. (2000). Differences in GDP per head in GB counties: Some suggested explanations. Applied Economics, 32(9), 1161-1167.

Hendricks, D., Patel, J., and Zeckhauser, R. (1993). Hot Hands in Mutual Funds: Short-Run Persistence of Relative Performance, 1974-1988. The Journal of Finance, 48(1), 93-130.

Hirsch, J., and Walz, U. (2017). The financing dynamics of newly founded firms. Journal of Banking \& Finance, 100, 261-272.

Huang, X., and Mahieu, R. J. (2011). Performance persistence of Dutch pension funds. De Economist, 160(1), 17-34.

Ippolito, R. A. (1993). On studies of mutual fund performance, 1962-1991. Financial Analysts Journal, $49(1), 42-50$.

Kim, Y., and Rous, J. (2012). House price convergence: Evidence from U.S. State and Metropolitan Area Panels. Journal of Housing Economics, 21(2), 169-186.

Kusideł, E., Kucharska-Stasiak, E., Załęczna, M., and Żelazowski, K. (2020). Procesy konwergencji na europejskich rynkach mieszkaniowych. Ujęcie międzynarodowe i regionalne. Łódź: Wydawnictwo Uniwersytetu Łódzkiego.

Matkowski, Z., Próchniak, M. and Rapacki, R. (2013). Nowe i stare kraje Unii Europejskiej: konwergencja czy dywergencja?, Prace i Materiaty Instytutu Rozwoju Gospodarczego/Szkoła Główna Handlowa, 91(2), 63-98.

MacDonald, R., and Taylor, M. (1993). Regional house prices in Britain: Long-run relationships and short-run dynamics. Scottish Journal of Political Economy, 40(1), 43-55.

McDonald, J. G. (1974). Objectives and performance of mutual funds, 1960-1969. The Journal of Financial and Quantitative Analysis, 9(3), 311-333.

Perez, K. (2012). Efektywność funduszy inwestycyjnych. Podejście techniczne oraz fundamentalne. Warszawa: Difin.

Perez, K. (2012). Fundusze inwestycyjne. Warszawa: Wolters Kluwer.

Philpot, J., Hearth, D., Rimbey, J. N., and Schulman, C. T. (1998). Active management, fund size, and bond mutual fund returns. The Financial Review, 33(2), 115-125.

Polwitoon, S., and Tawatnuntachai, O. (2006). Diversification benefits and persistence of US-based global bond funds. Journal of Banking \& Finance, 30(10), 2767-2786.

Próchniak, M. (2019). Konwergencja beta, sigma i gamma krajów postsocjalistycznych do Europy Zachodniej. Rocznik Instytutu Europy Środkowo-Wschodniej, 17(1), 217-243.

Rao, Z. U. R., Iqbal, A., and Tauni, M. Z. (2016). Performance persistence in institutional investment management: The case of Chinese equity funds. Borsa Istanbul Review, 16(3), 146-156. 
Sharpe, W. F. (1966). Mutual fund performance. The Journal of Business, 39(1), 119-138.

Twardowska, A. (2019). Konwergencja typu sigma cen gruntów rolnych w państwach Unii Europejskiej. Problemy Rolnictwa Światowego, 19(XXXIV) (1), 133-143.

Wyrzykowski, P. (2015). Konwergencja cen żywności w Unii Europejskiej. Roczniki Naukowe, XVII(4), 356-361.

Żelazowski, K. (2018). Konwergencja na regionalnych rynkach mieszkaniowych w Polsce. Ekonomia XXI Wieku, 3(19), 53-64.

\section{UTRZYMYWANIE WYNIKÓW INWESTYCYJNYCH ORAZ WYSTECPOWANIE ZJAWISKA GAMMA KONWERGENCJI NA RYNKU FUNDUSZY ABSOLUTNEJ STOPY ZWROTU W POLSCE W LATACH 2011-2018}

Streszczenie: W artykule podjęto próbę analizy wyników inwestycyjnych funduszy absolutnej stopy zwrotu w latach 2011-2018 w Polsce z punktu widzenia ich utrzymywania (performance persistence) oraz występowania zjawiska gamma konwergencji. Zostały zweryfikowane dwie hipotezy badawcze. Pierwsza dotyczy niewystępowania zjawiska utrzymywania wyników inwestycyjnych przez fundusze absolutnej stopy zwrotu, druga natomiast - występowania zjawiska gamma konwergencji na rynku funduszy absolutnej stopy zwrotu. Przyjęte metody badawcze, tj. tabela liczebności warunkowych jako nieparametryczna metoda pomiaru utrzymywania wyników inwestycyjnych oraz gamma konwergencja jako jedna z miar konwergencji, pozwoliły na wyciągnięcie odpowiednich wniosków. W większości analizowanych przypadków nie stwierdzono występowaniu zjawiska utrzymywania wyników inwestycyjnych. Otrzymane rezultaty potwierdzają występowanie zjawiska gamma konwergencji na rynku funduszy absolutnej stopy zwrotu.

Słowa kluczowe: performance persistence, fundusze absolutnej stopy zwrotu, konwergencja gamma. 